\title{
Pharmacoeconomic study of antipsychotic drugs in India
}

\author{
S. Nagaraja Prasad ${ }^{1}$, Vedavathi H. ${ }^{2}$
}

${ }^{1}$ Assistant Professor, ${ }^{2}$ Professor and HOD, Department of Pharmacology, Shivamogga Institute of Medical Sciences, Shimoga, Karnataka, India

Received: 05 December 2016 Accepted: 27 December 2016

\section{*Correspondence to:}

Dr. S. Nagaraja Prasad,

Email:

drnagarajprasad@gmail.com

Copyright: (C) the author(s), publisher and licensee Medip Academy. This is an openaccess article distributed under the terms of the Creative Commons Attribution NonCommercial License, which permits unrestricted noncommercial use, distribution, and reproduction in any medium, provided the original work is properly cited.

\begin{abstract}
Background: Schizophrenia is a disorder of relatively high point prevalence, low incidence and high disability. It accounts for nearly $1.5-3 \%$ of total national expenditure on health care. There is a gross variation in the cost of various branded and generic versions of antipsychotics available in India. This can lead to decreased patient compliance. The present study was undertaken to highlight this variation in the cost of various preparations of antipsychotics (branded and generic) available in India.
\end{abstract}

Methods: Cost ratio and Percentage variation in cost of various antipsychotics available were calculated by standard formulae and analysed.

Results: There is a very high variation in the cost of various antipsychotics available in India. The highest variation in cost ratio was seen with risperidone $2 \mathrm{mg}$, $3 \mathrm{mg}$ and olanzapine $10 \mathrm{mg}$, while the highest percentage cost variation was seen with risperidone $3 \mathrm{mg}, 4 \mathrm{mg}, 1 \mathrm{mg}$; olanzapine $2.5 \mathrm{mg}, 5 \mathrm{mg}, 50 \mathrm{mg}$, $100 \mathrm{mg}$; levosulpiride $25 \mathrm{mg}$ and chlorpromazine $20 \mathrm{mg}$. The lowest percentage cost variation was seen with Flupenthixol $3 \mathrm{mg}$ and Amisulpiride 300mg.

Conclusions: There is a definite need to further strengthen the Drug Price Regulatory Mechanisms with regard to antipsychotics available in India in order to improve the patient compliance and thus cure rates of this burdensome and costly illness.

Keywords: Anti-psychotics, Cost - analysis, Cost ratio, Pharmacoeconomics, Percentage cost variation

\section{INTRODUCTION}

Emil Kraeplin first described two major types of insanity: maniac depressive psychosis and dementia praecox (dementia of young). Later on in 1911 the term Schizophrenia was introduced by Eugene Bleuler. ${ }^{1}$ The point and lifetime prevalence rates of schizophrenia were 4.6 and 4 respectively. The incidence of schizophrenia is about $0.20 / 1000 /$ year. The prevalence of schizophrenia is much more in the developing countries and it typically occurs a little earlier in males compared to females. The peak incidence for males and females is during 15-24 years. Males have a higher lifetime risk of schizophrenia and meta-analysis revealed that males have a $30-40 \%$ higher lifetime risk of developing schizophrenia. ${ }^{2}$

Schizophrenia can be said to be a disorder of a relatively high point prevalence, low incidence and high disability. ${ }^{3}$ The impact of schizophrenia is typically estimated to be
$1.5 \%$ to $3 \%$ of total national spending on health care. ${ }^{4}$ In developed countries the direct costs of schizophrenia amount to $1.4-2.8 \%$ of the national health care expenditure and upto $1 / 5^{\text {th }}$ of the direct health care costs of all mental disorders. ${ }^{1}$ Various economic evaluations have been done in past with regard to schizophrenia like the CATIE study (Clinical Antipsychotic Trials of Intervention Effectiveness), CUtLASS study (Cost Utility of The Latest Antipsychotic drugs in Schizophrenia Study), and SOHO study (European Schizophrenia Outpatient Health Outcomes) which did not demonstrate a very wide differences in cost outcomes between use of typical and atypical antipsychotics. ${ }^{2,5}$ Although it is not a very common disease Schizophrenia can be said to be one of the most burdensome and costly illness worldwide and this has a huge impact on the treatment compliance by the patient. ${ }^{6}$

The Indian pharmaceutical industry is estimated to be worth around US\$20 billion and is said to be the third 
largest with respect to volume and $13^{\text {th }}$ in terms of value as per a report by equity master. ${ }^{7}$ The pharmaceutical industries tend to promote their branded products vigorously by various modes of advertising and physicians tend to prescribe these branded products over the generic drugs available. All these costs are ultimately to be met by the patient himself from his own expenses thus increasing their financial burden. ${ }^{8,9}$ It is a commonly observed fact that there is a gross variation in the cost of different branded preparations of the same drug this is because the pharmaceutical companies tend to produce both generic as well as branded versions of the same drug and increase the cost of the branded preparations by adding some excipients or by making a formulation by different method. And it has been observed that the generic and branded version of the same drug prepared by the same company do not differ greatly in terms of bioavailability or other parameters. This difference in cost has affected both the consumers to great extent and healthcare providers regarding which is the most suitable branded and generic preparation of drug.

This aspect of differential pricing of medicines has to some extent been taken care of by Government of India through periodic notification of Drug Price Control Order (DPCO) which fixes the prices of certain drugs which are essential and makes them affordable. ${ }^{10,11}$ This in turn is implemented by the National Pharmaceutical Pricing Authority (NPPA). ${ }^{11,12}$

Cost analysis is a type of partial pharmacoeconomic evaluation in which comparison of cost of two or more alternatives is made without regard to outcome. ${ }^{13}$ The consideration of cost of treatment is one of the important aspect in health economics. One of the most important costs that the patient has to bear is the acquisition cost of medicines. However the physicians tend to prescribe branded preparations over generic ones as they assume the branded preparations to be much more superior to generic versions of the same drug. Cost related poor patient compliance is a worldwide problem. Poor or noncompliance to treatment affects clinical outcome and thereby increases the total health care costs borne by patients who may not complete the full course of treatment because of higher cost of therapy.

Hence the present study was undertaken to study the cost difference of different antipsychotic drugs available in the Indian market and to highlight the cost variation among different branded and generic preparations available in the Indian market so that whenever possible a cheaper cost-effective medicine can be prescribed to ensure better patient compliance and to reduce medicine cost to patient as well as total health care costs.

\section{METHODS}

Prices of various antipsychotic drugs were recorded from the following sources:
- $\quad$ CIMS July-Oct 2016

- Indian Drug Review Vol XXII, Issue 3, 2016.

- $\quad$ Drug Today July to Oct 2016.

The following method was followed:

1. The minimum and maximum cost in rupees (INR) of a particular antipsychotic drug manufactured by different pharmaceutical companies in the same dose strength is noted.

2. The costs of 10 tablets are calculated.

3. The cost ratio (ratio of the maximum cost of the drug to the minimum cost of the drug) of the same generic drug was calculated. This gives an indication of how many times costliest brand drug cost with regard to the cheapest brand of the drug.

4. Percentage cost variation was calculated as follows:

5. $\%$ cost variation $=$ (maximum cost-minimum cost/minimum cost) X 100 .

6. Fixed drug combinations and parenteral preparations were also evaluated in the same manner as above.

\section{RESULTS}

The prices of a total of 23 oral preparations of antipsychotics, five parenteral preparations and four fixed dose combinations of antipsychotics manufactured by different pharmaceutical companies were evaluated in the present study (Table 1, 2 and 3).

The present study reveals that there is a great variation in the prices of different formulations of antipsychotics available in the Indian market. The highest cost ratio was seen with risperidone $2 \mathrm{mg}$ (1:20.93), $3 \mathrm{mg}$ (1:20.15) and olanzapine $10 \mathrm{mg}(1: 18.8)$.

\section{The highest percentage cost variation was seen among}

Risperidone 3mg (1914.93\%), 4mg (1730.5\%), $1 \mathrm{mg}$ (1724.32\%); olanzapine $2.5 \mathrm{mg} \quad(1516.16 \%)$, $5 \mathrm{mg}$ (1240.78\%), 50mg (1190.78\%), 100mg (1002.77\%); levosulpiride $25 \mathrm{mg}(975 \%)$; chlorpromazine $200 \mathrm{mg}$ (962.84\%).

\section{The lowest percentage cost variation was seen among}

Flupenthixol 3mg (5.16\%); Amisulpiride 300mg (13.53\%); haloperidol $2 \mathrm{mg}(21.93 \%)$; trifluperidol $0.5 \mathrm{mg}$ $(21.74 \%)$; thioridazine $5 \mathrm{mg}(28.67 \%)$; ziprasidone $80 \mathrm{mg}$ $(29.60 \%)$.

\section{DISCUSSION}

The vast majority of people who are affected by Schizophrenia reside in developing countries. This creates a lot of burden on the health economies of these countries. 
Table 1: Oral dose formulation of antipsychotics.

\begin{tabular}{|c|c|c|c|c|c|c|}
\hline SI. No & DRUG & Dose & $\begin{array}{l}\text { Minimum } \\
\text { cost }(\mathbf{R s})\end{array}$ & $\begin{array}{l}\text { Maximum } \\
\text { cost }(\mathbf{R s})\end{array}$ & Cost ratio & $\%$ Of price variation of $\mathbf{1 0}$ tablets \\
\hline \multirow{5}{*}{1} & \multirow{5}{*}{ Chlorpromazine } & $10 \mathrm{mg}$ & --- & 4.05 & 1 & 0 \\
\hline & & $25 \mathrm{mg}$ & 1.82 & 6.27 & 3.45 & 244.51 \\
\hline & & $50 \mathrm{mg}$ & 2.82 & 36.40 & 12.91 & 1190.78 \\
\hline & & $100 \mathrm{mg}$ & 5.06 & 55.80 & 11.03 & 1002.77 \\
\hline & & $200 \mathrm{mg}$ & 9.07 & 96.40 & 10.63 & 962.84 \\
\hline \multirow{5}{*}{2} & \multirow{5}{*}{ Thioridazine } & $5 \mathrm{mg}$ & 4.43 & 5.70 & 1.29 & 28.67 \\
\hline & & $10 \mathrm{mg}$ & 9 & 16 & 1.78 & 77.78 \\
\hline & & $25 \mathrm{mg}$ & 14.80 & 28 & 1.89 & 89.19 \\
\hline & & $50 \mathrm{mg}$ & 30.45 & 54 & 1.77 & 77.34 \\
\hline & & $100 \mathrm{mg}$ & 52 & 72 & 1.38 & 38.46 \\
\hline 3 & Trifluperazine & $5 \mathrm{mg}$ & 4.48 & 10 & 2.23 & 123.21 \\
\hline \multirow{5}{*}{4} & \multirow{5}{*}{ Thioridazine } & $5 \mathrm{mg}$ & 4.43 & 5.70 & 1.29 & 28.67 \\
\hline & & $10 \mathrm{mg}$ & 9 & 16 & 1.78 & 77.78 \\
\hline & & $25 \mathrm{mg}$ & 14.80 & 28 & 1.89 & 89.19 \\
\hline & & $50 \mathrm{mg}$ & 30.45 & 54 & 1.77 & 77.34 \\
\hline & & $100 \mathrm{mg}$ & 52 & 72 & 1.38 & 38.46 \\
\hline \multirow{8}{*}{5} & \multirow{8}{*}{ Haloperidol } & $0.25 \mathrm{mg}$ & 1.96 & 15 & 7.65 & 665.31 \\
\hline & & $0.5 \mathrm{mg}$ & ---- & 22.80 & 1 & 0 \\
\hline & & $1.5 \mathrm{mg}$ & 4.10 & 17 & 4.15 & 314.63 \\
\hline & & $2 \mathrm{mg}$ & 15.87 & 19.35 & 1.22 & 21.93 \\
\hline & & $2.5 \mathrm{mg}$ & ---- & 9.72 & 1 & 0 \\
\hline & & $5 \mathrm{mg}$ & 9.25 & 42 & 4.54 & 354.05 \\
\hline & & $10 \mathrm{mg}$ & 16.13 & 69 & 4.28 & 327.77 \\
\hline & & $20 \mathrm{mg}$ & 45.12 & 59.41 & 1.32 & 31.67 \\
\hline 6 & Trifluperidol & $0.5 \mathrm{mg}$ & 23 & 28 & 1.22 & 21.74 \\
\hline 7 & Penfluridol & $20 \mathrm{mg}$ & --- & 91.25 & 1 & 0 \\
\hline \multirow{3}{*}{8} & \multirow{3}{*}{ Flupenthixol } & $0.5 \mathrm{mg}$ & $20.25 \mathrm{mg}$ & 60 & 2.96 & 196.30 \\
\hline & & $1 \mathrm{mg}$ & 35.85 & 76 & 2.12 & 111.99 \\
\hline & & $3 \mathrm{mg}$ & 76.50 & 80.45 & 1.05 & 5.16 \\
\hline \multirow{4}{*}{9} & \multirow{4}{*}{ Clozapine } & $12.5 \mathrm{mg}$ & --- & 17 & 1 & 0 \\
\hline & & $25 \mathrm{mg}$ & 9.80 & 28.50 & 2.91 & 190.82 \\
\hline & & $50 \mathrm{mg}$ & 28 & 53 & 1.89 & 89.29 \\
\hline & & $100 \mathrm{mg}$ & 26.80 & 82 & 3.06 & 205.97 \\
\hline \multirow{6}{*}{10} & \multirow{6}{*}{ Olanzapine } & $2.5 \mathrm{mg}$ & 9.90 & 160 & 16.17 & 1516.16 \\
\hline & & $5 \mathrm{mg}$ & 17.90 & 240 & 13.41 & 1240.78 \\
\hline & & $7.5 \mathrm{mg}$ & 21.90 & 61 & 2.79 & 178.54 \\
\hline & & $10 \mathrm{mg}$ & 25 & 470 & 18.8 & 1780 \\
\hline & & $15 \mathrm{mg}$ & 60 & 88 & 1.47 & 46.67 \\
\hline & & $20 \mathrm{mg}$ & 80 & 114.30 & 1.43 & 42.88 \\
\hline \multirow{6}{*}{11} & \multirow{6}{*}{ Quetiapine } & $25 \mathrm{mg}$ & 13.79 & 35 & 2.54 & 153.81 \\
\hline & & $50 \mathrm{mg}$ & 25 & 48 & 1.92 & 92 \\
\hline & & $100 \mathrm{mg}$ & 36.59 & 66 & 1.80 & 80.38 \\
\hline & & $200 \mathrm{mg}$ & 69.13 & 120 & 1.74 & 73.59 \\
\hline & & $300 \mathrm{mg}$ & 105 & 165 & 1.57 & 57.14 \\
\hline & & $400 \mathrm{mg}$ & ---- & 185 & 1 & 0 \\
\hline \multirow{3}{*}{12} & \multirow{3}{*}{ Sulpiride } & $100 \mathrm{mg}$ & --- & 33 & 1 & 0 \\
\hline & & $200 \mathrm{mg}$ & --- & 66 & 1 & 0 \\
\hline & & $400 \mathrm{mg}$ & --- & 99 & 1 & 0 \\
\hline & & $25 \mathrm{mg}$ & --- & 30 & 1 & 0 \\
\hline & & $50 \mathrm{mg}$ & 40 & 65 & 1.625 & 62.5 \\
\hline 12 & A migulnirid & $100 \mathrm{mg}$ & 65 & 95 & 1.4615 & 46.15 \\
\hline 13 & Amisulpiride & $200 \mathrm{mg}$ & 112 & 187 & 1.6696 & 66.96 \\
\hline & & $300 \mathrm{mg}$ & 207 & 235 & 1.135 & 13.53 \\
\hline & & $400 \mathrm{mg}$ & ---- & 309 & 1 & 0 \\
\hline
\end{tabular}


Table 1: Oral dose formulation of antipsychotics.

\begin{tabular}{|c|c|c|c|c|c|c|}
\hline Sl. No & Drug & Dose & $\begin{array}{l}\text { Minimum } \\
\text { cost }(\mathrm{Rs})\end{array}$ & $\begin{array}{l}\text { Maximum } \\
\text { cost }(\mathbf{R s})\end{array}$ & Cost ratio & $\%$ Of price variation of $\mathbf{1 0}$ tablets \\
\hline \multirow{5}{*}{14} & \multirow{5}{*}{ Risperidone } & $0.5 \mathrm{mg}$ & ---- & 15 & 1 & 0 \\
\hline & & $1 \mathrm{mg}$ & 7.40 & 135 & 18.24 & 1724.32 \\
\hline & & $2 \mathrm{mg}$ & 12.90 & 270 & 20.93 & 199.30 \\
\hline & & $3 \mathrm{mg}$ & 20.10 & 405 & 20.15 & 1914.93 \\
\hline & & $4 \mathrm{mg}$ & 29.50 & 540 & 18.31 & 1730.5 \\
\hline \multirow{3}{*}{15} & \multirow{3}{*}{ Iloperidone } & $2 \mathrm{mg}$ & --- & 40 & 1 & 0 \\
\hline & & $4 \mathrm{mg}$ & --- & 55 & 1 & 0 \\
\hline & & $6 \mathrm{mg}$ & --- & 70 & 1 & 0 \\
\hline \multirow{2}{*}{16} & \multirow{2}{*}{ Levosulpiride } & $25 \mathrm{mg}$ & 12 & 129 & 10.75 & 975 \\
\hline & & $50 \mathrm{mg}$ & ---- & 96 & 1 & 0 \\
\hline \multirow{4}{*}{17} & \multirow{4}{*}{ Paliperidone } & $1.5 \mathrm{mg}$ & --- & 27 & 1 & 0 \\
\hline & & $3 \mathrm{mg}$ & --- & 39 & 1 & 0 \\
\hline & & $6 \mathrm{mg}$ & --- & 75 & 1 & 0 \\
\hline & & $9 \mathrm{mg}$ & --- & 105 & 1 & 0 \\
\hline \multirow{5}{*}{18} & \multirow{5}{*}{ Aripiprazole } & $5 \mathrm{mg}$ & 36 & 47 & 1.31 & 30.56 \\
\hline & & $10 \mathrm{mg}$ & 50 & 114 & 2.28 & 128 \\
\hline & & $15 \mathrm{mg}$ & 70 & 195 & 2.79 & 178.57 \\
\hline & & $20 \mathrm{mg}$ & 98 & 237 & 2.42 & 141.84 \\
\hline & & $30 \mathrm{mg}$ & 97.10 & 177.35 & 1.83 & 82.65 \\
\hline \multirow{4}{*}{19} & \multirow{4}{*}{ Ziprasidone } & $20 \mathrm{mg}$ & 30.20 & 44.30 & 1.47 & 46.69 \\
\hline & & $40 \mathrm{mg}$ & 59.90 & 89 & 1.49 & 48.58 \\
\hline & & $60 \mathrm{mg}$ & ---- & 89 & 1 & 0 \\
\hline & & $80 \mathrm{mg}$ & 119.60 & 155 & 1.30 & 29.60 \\
\hline \multirow{2}{*}{20} & \multirow{2}{*}{$\begin{array}{l}\text { Asenapine } \\
\text { maleate }\end{array}$} & $5 \mathrm{mg}$ & --- & 55 & 1 & 0 \\
\hline & & $10 \mathrm{mg}$ & ---- & 85 & 1 & 0 \\
\hline \multirow{3}{*}{21} & \multirow{3}{*}{ Pimozide } & $2 \mathrm{mg}$ & 11.50 & 33.88 & 2.95 & 194.61 \\
\hline & & $4 \mathrm{mg}$ & 17.20 & 72.75 & 4.23 & 322.97 \\
\hline & & $10 \mathrm{mg}$ & --- & 110.29 & 1 & 0 \\
\hline \multirow{3}{*}{22} & \multirow{3}{*}{ Loxapine } & $10 \mathrm{mg}$ & 13.33 & 34.12 & 2.56 & 155.96 \\
\hline & & $25 \mathrm{mg}$ & 26.66 & 71 & 2.66 & 166.32 \\
\hline & & $50 \mathrm{mg}$ & --- & 127.40 & 1 & 0 \\
\hline 23 & Prochlorperazine & $5 \mathrm{mg}$ & --- & 41 & 1 & 0 \\
\hline
\end{tabular}

Table 2: Parenteral preparations of antipsychotics.

\begin{tabular}{|lllllll|}
\hline SI. no & Drug & Dose & $\begin{array}{l}\text { Minimum } \\
\text { cost }(\text { Rs })\end{array}$ & $\begin{array}{l}\text { Maximum } \\
\text { cost (Rs) }\end{array}$ & $\begin{array}{l}\text { Cost ratio } \\
\text { Cost } \\
\text { variation }\end{array}$ \\
\hline 1 & Chlorpromazine & Inj $25 \mathrm{mg} / \mathrm{ml}(2 \mathrm{ml})$ & 2.14 & 21.20 & & 0 \\
\hline 2 & Flupenthixol & Inj $20 \mathrm{mg} / \mathrm{ml}$ & --- & 97.70 & 1 & 26.26 \\
\hline 3 & Fluphenazine & Inj $25 \mathrm{mg} / \mathrm{ml}$ & 23.76 & 30 & 1.26 & 66.67 \\
\hline \multirow{2}{*}{4} & \multirow{2}{*}{ Haloperidol } & Inj $5 \mathrm{mg} / \mathrm{ml}(1 \mathrm{ml})$ & 4.50 & 7.50 & 1.67 & 46.86 \\
\cline { 3 - 7 } & Zuclopenthixol & Inj $50 \mathrm{mg} / \mathrm{ml}(1 \mathrm{ml})$ & 112.35 & 165 & 1.47 & 0 \\
\hline 5 & & & --- & 81.75 & 1 & 0 \\
\hline
\end{tabular}

Table 3: Fixed dose combinations of antipsychotics.

\begin{tabular}{|c|c|c|c|c|c|c|}
\hline Sl. no & Drug & Dose & $\begin{array}{l}\text { Minimum } \\
\text { cost (Rs) }\end{array}$ & $\begin{array}{l}\text { Maximum } \\
\text { cost }(\text { Rs })\end{array}$ & Cost ratio & $\begin{array}{l}\% \text { Cost } \\
\text { variation }\end{array}$ \\
\hline 1 & Haloperidol+trihexiphenidyl & $5 m g+2 m g$ & ---- & 24 & 1 & 0 \\
\hline \multirow{2}{*}{2} & \multirow{2}{*}{ Olanzapine+ fluoxetine } & $5 m g+20 m g$ & 60 & 81.50 & 1.36 & 35.83 \\
\hline & & $10 \mathrm{mg}+20 \mathrm{mg}$ & ----- & 86 & 1 & 0 \\
\hline \multirow{3}{*}{3} & \multirow{3}{*}{ Risperidone+trihexiphenidyl } & $2 m g+2 m g$ & 21 & 38 & 1.81 & 80.95 \\
\hline & & $3 m g+2 m g$ & 30 & 54 & 1.8 & 80 \\
\hline & & $4 m g+2 m g$ & 36.50 & 56 & 1.53 & 53.42 \\
\hline \multirow{2}{*}{4} & \multirow{2}{*}{ Trifluperazine+ trihexiphenidyl } & $5 m g+2 m g$ & 8.30 & 21 & 2.53 & 153.01 \\
\hline & & $10 m g+2 m g$ & --- & 20 & 1 & 0 \\
\hline
\end{tabular}


This situation is further complicated by pressures of economic development, increasing income inequality, unemployment and cuts in public spending on health care. The traditional societal values may bear the brunt of rapid economic expansion and this may further increase the prevalence of schizophrenia in developing country like India. ${ }^{1}$

Medication adherence refers to the extent of conformity to treatment recommendation with respect to the timing, dosage, frequency and duration of a prescribed medicine. ${ }^{14}$ It may also be described as the degree to which a patient correctly follows medical advice. Medication compliance is a major concern especially among the schizophrenics. Patients are considered adherent to treatment when they take prescribed drugs at doses and at time recommended by health care practitioners. ${ }^{15}$ Factors contributing to patient noncompliance include: cost of drugs, side effects of drugs, drug formulation, improvement of symptoms, forgetfulness, frequent dosing etc. ${ }^{16,17}$

In India many pharmaceutical companies sell drugs of different generic names and this has led to wide variation in price of branded and generic formulation of these drugs. Also factors like government regulations, cost of raw products, drug distribution and promotion costs, economic goals of company and target return on principal investment also contribute to the wide variation in price of drugs. ${ }^{18,19}$

An expensive brand can cost a patient more than ten times the price of a cheaper brand of the same drug. This reflects a serious concern in the context of India where health insurance has still not reached the poorer sections of society and $50-90 \%$ of cost of medicines still borne by patient himself. $^{20-22}$ Consumers are likely to suspect low quality from market price, non-innovator brand and the look of the product, but none of these signals can perfectly identify substandard and counterfeit drugs. ${ }^{21}$

The present study reveals a high percentage cost variation (>1000\%) among the commonly used antipsychotic drugs like Risperidone $3 \mathrm{mg}$, $4 \mathrm{mg}$, $1 \mathrm{mg}$; Olanzapine $2.5 \mathrm{mg}$, $5 \mathrm{mg}$ and Chlorpromazine 50mg, 100mg. The lowest percentage cost variation was seen with Flupenthixol $3 \mathrm{mg}$ (5.16\%), Amisulpiride 300mg (13.53\%) and Haloperidol (21.93\%).

Clinician's ignorance and false belief of effectiveness of superiority of branded drugs over generic drugs result in prescription of costly drugs, when cheaper alternatives are already available. This often leads to non-compliance or sometimes partial compliance by patients. Prescription of good quality generic drugs which are as effective as branded drugs (because even the generic drug manufacturers have to comply with good manufacturing practices), would lead to improved compliance by the patient with regard to antipsychotic drug usage and thus cause an improvement on outcomes of a serious disease like schizophrenia.

\section{CONCLUSION}

The present study reveals that there is a need to further improve the drug price regulatory mechanism as it was found that there was a very wide variation (upto 1000\%) of some of the commonly used antipsychotic drug preparations. Physician's knowledge of such price variation of commonly used antipsychotics and his due consideration of the pharmacoeconomic status of the patient while prescribing antipsychotics can greatly improve the drug compliance by patient and thus lead to improved cure rates of this burdensome and costly illness worldwide.

\section{ACKNOWLEDGEMENTS}

The authors are thankful to the Director/Dean of Shivamogga Institute of Medical Sciences, Shimoga for giving permission to conduct this study.

\section{Funding: No funding sources}

Conflict of interest: None declared

Ethical approval: The study was approved by the Institutional Ethics Committee

\section{REFERENCES}

1. Sadock BJ, Sadock VA, Reiz P Ed. Kaplan and Sadock's Comprehensive textbook of psychiatry. $9^{\text {th }}$ ed. Wolter Kluwer, Lippincott Williams and Wilkins. 2009;1:1432-628.

2. Tsuang MJ, Tohen M, Jones PB. Textbook of psychiatric epidemiology 3rd ed. Wiley Blackwell, A John Wiley and sons; 2011:257-269.

3. Vyas JN, Ahuja N. Textbook of postgraduate psychiatry $2^{\text {nd }}$ ed, Vol 1 . Jaypee publications; 1999 reprint; 2008:150-187.

4. Knapp M, Mangalore R, Simon J. The global costs of schizophrenia. Schizophr Bull. 2004;30(2):279-93.

5. Kasper S, Papadimitriou GN Ed. SchizophreniaPsychosocial approaches and current challenges. $2^{\text {nd }}$ ed Informa UK ltd; 2009:362-276.

6. Rossler W, Salize HJ, Van Os J, Riecher-Rossler A. Size of burden of schizophrenia and psychotic disorders. Eur Neuropsychopharmacol. 2005;15(4):399-409.

7. India Brand Equity Foundation. Available at http://www.ibef.org/industry/pharmaceuticalIndia.aspx.

8. Panchal SS, Pandit PR, Pathak AM, Lohi KM. Cost analysis of antiretroviral agents available in India. Int J Basic Clin Pharmacol. 2015:4:479-82.

9. Das SC, Mandal M, Mandal SC. A critical study on availability and price variation between different brands: impact on access to medicines. Indian $\mathbf{J}$ Pharm Sci. 2007;69(1):160-3. 
10. Gazette of India-Extraordinary Part II-Sec 3(ii). Drug Price control Order, New Delhi. Ministry of Chemical and Fertilizers, Department of Pharmaceuticals (National Pharmaceutical Pricing Authority) 2013:2:36-67. Available at http://www.pharmaceuticals.gov.in/DPCO.

11. National list of Essential medicines 2015. Available at http://www.cdsco.nic.in/NLEM 2015/Recommendations.pdf.

12. National Pharmaceutical Pricing Authority, Government of India. Available at http://www.nppaindia.nic.in/DPCO 2013 pdf.

13. Ahuja J, Gupta M, Gupta AK, Kohli K. Pharmacoeconomics. Natl Med J India. 2004;17(2):80-3.

14. Cramer JA, Roy A, Burrell A, Fairchild CJ, Fuldeore MJ, Olendorf DA, et al. Medication compliance and persistence: Terminology and definitions. Value in Health. 2008;11:44-47.

15. Osterberg L, Blaschke T. Adherence to medication. N Eng J Med. 2005;353(5):487-97.

16. Piette JD, Beard A, Rosland AM, Mc Horney CA. Beliefs that influence cost related medication nonadherence among the 'haves' and "have nots" with chronic diseases. Patient Preference and Adherence. 2011;5:389-96.

17. Kardas P, Bishai WR. Compliance in infective medicine. Adv Stud Med. 2006;6(7):652-8.

18. Berki SE, Richards JW, Weeks HA. The mysteries of prescription pricing in retail pharmacies. Med Care. 1977;15(3):241-50.

19. Wertheimer AI, Grumer SK. Overview of international pharmacy pricing. Pharmacoeconomics. 1992;2(1):449-55.

20. The World Medicines Situation. World Health Organization 2011. Available at http://www.who.int/medicines/areas/policy/world_m edicines_situation/em/index.html

21. Bate R, Jin GZ, Mathur A. Does price reveal poor quality drugs? Evidence from 17 countries. J Health Economics. 2011;30(6):1150-63.

22. Mohan S, Campbell N, Chokalingam D. Time to effectively address hypertension in India. Ind $\mathrm{J}$ Med Res. 2013;137:627-31.

Cite this article as: Prasad SN, Vedavathi $\mathrm{H}$. Pharmacoeconomic study of antipsychotic drugs in India. Int J Basic Clin Pharmacol 2017;6:377-82. 